\title{
Dietary Pattern and Stress Scale of the Working Women (25 to 45 Years) in Coimbatore
}

\author{
Lakshmi Praba.V'ackia Anishmi Linda.E ${ }^{1}$ Mithusha. $C^{1}$ Pooja Poornima.S ${ }^{1}$ and Premagowri.B ${ }^{2}$ \\ PG Student, Department of Clinical Nutrition and Dietetics, PSG CAS, Coimbatore, Tamilnadu, India ${ }^{1}$ \\ Assistant Professor, Department of Clinical Nutrition and Dietetics, PSG CAS, Coimbatore, Tamilnadu, India ${ }^{2}$
}

\begin{abstract}
A woman's health in her total well-being is not determined solely by her biological factors and reproduction, but also by effects of work load, nutrition, stress, war and migration, among others. Most of the time women takes care of her family and ignores own health, so awareness generation is needed to promote the health of the women. The study was focused to know the dietary pattern and stress level among 100 randomly selected working women of age group 25 to 45 years in Coimbatore. The interview schedule was framed to collect the data about socio-demographic profile, anthropometric status, dietary pattern and stress level. About $6 \%$ of the subjects were underweight, $38 \%$ were with normal BMI, $28 \%$ overweight and $28 \%$ were obese. Intake of energy, protein, fibre, iron and calcium were found to be deficit whereas fat intake was found to be excess among the selected working subjects. The perceived stress Scale was used to analyze stress and found that $72 \%$ of the subjects - moderate stress, $28 \%$ of the subjects - high stress and none of the subjects have very low stress. Nutrition education was provided to all the selected working women by EPamphlet through mail which highlighted the importance of healthy food choices and physical activity. It was concluded that the nutritional status of the working women is comparatively low and the stress level is moderate to high and there is no relationship between nutrient intake and stress level.
\end{abstract}

Key Words: Anthropometry, dietary pattern, stress, nutrition education

\section{INTRODUCTION}

The health of women is linked to their status in the society. The demographic consequence of the women has formed expression in various forms, such as female infanticide, higher death rate, lower sex ratio, low literacy level and lower level of employment of women in the non-agricultural sector as compared to men. Generally, at household level, cultural norms and practices and socio-economic factors determine the extent of nutritional status among women. Women constitute about half of our country's population. In the recent years with the increasing access to education it has resulted in their intellectual awakening and money earning capacity. But women in India are still more susceptible to and are trapped in the vicious cycle of disease and illness because of prevailing culture and traditional practices and as a result the overall health and nutritional status of women becoming worse affected. Malnutrition adversely affects women's participation in the economic system and their productivity. To break this fierce paradox it is important to focus simultaneously on women's nutrition-related roles and their nutritional status [1].

The educational level, position, health and nutritional status of the women are central to the quality of life and are key determinants of family health [2]. It is usually believed that women's employment has potential to benefit in increasing household income as well as household nutrition if the decision making and income disposal power are exercised by them. Food habits are predictors of health and nutritional status. Culture and socio economic status of the population influence food choices and pattern of consumption, while consumption of some food items is likely to vary according to season and often based on availability and price. Education and income have been shown to be important determinants in food intake.

Study done by [3] indicated that when the nutritional status was assessed majority of working women maintained normal BMI, $25 \%$ of women were under weight and $18 \%$ of women were overweight. Total $76 \%$ of the respondents were under the high disease risk condition in waist hip ratio, $13 \%$ were at elevated risk and $11 \%$ was reduced risk condition. The nutrient intake of the respondents were calories (93\%), protein (87\%) and zinc (64\%) was less than RDA but the intake of Fat (188\%), and Calcium (125\%) was more than RDA. Majority of the respondents had high knowledge about balance diet $(70 \%)$ in addition to health status (59\%).

So the present study was designed with the following objectives as to know the socio-demographic profile, anthropometric status, dietary pattern and stress level of the selected working women of age group 25 to 45 years in Coimbatore and to provide nutrition education with e- posters on mindful eating, food choices, importance of physical activity and stress management to all the selected subjects on lifestyle modifications. 
Vol. 8, Issue 6, June 2021

\section{DOI: $10.17148 /$ IARJSET.2021.8604}

\section{METHODOLOGY}

Around 100 working women were purposively selected for the study. The data regarding the socio-demographic profile, anthropometric status, dietary pattern and stress level were collected using the interview schedule designed by the investigator. The nutritive value was calculated using 24 hours recall method. The Perceived stress scale was used to collect the needed information regarding stress which also affects the food intake of the subjects. Mean and standard deviation was calculated to express the results. The relationship between stress and nutrient intake was analysed by using the statistical tool SPSS version 19 and the results were examined. Nutrition education was provided to all the selected working women. Pamphlet was prepared by the investigator(s) on importance of breakfast, healthy food choices and physical activity. Individual counseling was provided to all the selected subjects regarding their nutrient intake.

\section{A. Background Information of Selected Subjects}

\section{RESULTS \& DISCUSSION}

1) Age Group of the Selected Subjects:

Among the selected subjects, $44 \%$ of the subjects were between $25-30$ years of age, $32 \%$ belongs to the age group of 31-35years, $12 \%$ were $36-45$ years of age and the remaining $12 \%$ were under $40-45$ years of age.

2) Educational Qualification of the Selected Subjects:

Nearly eight percentage of the subjects have the educational qualification less than $10^{\text {th }}$ standard, two percentage of the subjects have completed $10^{\text {th }}$ standard, nine percentage of the subjects have completed $12^{\text {th }}$ standard and about $81 \%$ of the subjects are graduated.

3) Nativity, Marital Status, Family Type and Total Family Members of the Selected Subjects:

It was reported that $64 \%$ of the subjects were from urban and $36 \%$ of the subjects were from rural. Around $62 \%$ of the subjects were married and $38 \%$ of the subjects were unmarried. Nearly $63 \%$ of the selected subjects belongs nuclear family and $37 \%$ of the selected subjects belongs to joint family. Around 39\% of the selected subjects have less than 4 members in their family, $47 \%$ of the subjects have 4-6 members in their family, nine percentage of the subjects have 68 members in their family and five percentage of the subjects have more than 8 members in their family.

4) Type of Work and Monthly Income of the Selected Subjects:

Around $45 \%$ of the subjects are sedentary workers, $52 \%$ of the subjects are moderate workers and three percentage of the subjects are heavy workers. Around $12 \%$ of the subjects earn less than 10,000 per month, $71 \%$ of the subjects monthly income were between $11,000-30,000,11 \%$ of the subjects monthly income were between $30,000-50,000$ and only six percentage of the subjects earn above 50,000 per month.

\section{B. Anthropometric Status of All the Selected Working Women}

\section{1) Anthropometric Measures of all the Selected Working Women:}

The mean height was $162.74 \pm 10.02 \mathrm{~cm}$, weight was $62.33 \pm 12.11 \mathrm{~kg}$, BMI was $23.66 \pm 3.55 \mathrm{~kg} / \mathrm{m}^{2}$, waist circumference was $87.19 \pm 13.07 \mathrm{~cm}$, hip circumference was $97.91 \pm 8.03 \mathrm{~cm}$ and waist hip ratio was $0.88 \pm 0.11$.

2) Anthropometric Status of All the Selected Working Women:

Table I ANTHROPOMETRIC STATUS OF ALL THE SELECTED WORKING WOMEN

\begin{tabular}{|c|c|c|c|c|}
\hline \multirow[t]{2}{*}{ S. No. } & \multirow[t]{2}{*}{ Anthropometric Status } & \multirow{2}{*}{$\begin{array}{c}* \text { Reference BMI } \\
\left(\mathrm{kg} / \mathrm{m}^{2)}\right.\end{array}$} & \multicolumn{2}{|c|}{ Number of Samples $(n=100)$} \\
\hline & & & Numbers & Percentage \\
\hline 1 & Underweight & $<18.5$ & 6 & 6 \\
\hline 2 & Normal & $18.5-22.9$ & 38 & 38 \\
\hline 3 & Overweight & $23-24.9$ & 28 & 28 \\
\hline 4 & Obese & $\geq 25$ & 28 & 28 \\
\hline \multicolumn{3}{|c|}{ Total } & 100 & 100 \\
\hline
\end{tabular}

* Asia - Pacific guidelines

From the above table it was clear that six percentage of the subjects were underweight, $38 \%$ of the subjects were normal, $28 \%$ overweight, $28 \%$ of the subjects were obese.

\section{Nutritional Status of the Selected Subjects}

1) Food Habit of the Selected Subjects:

Nearly $24 \%$ of the subjects were vegetarian, $11 \%$ of the subjects were ova vegetarian and $65 \%$ of the subjects were non vegetarian.

\section{2) Meal Pattern of the Selected Subjects:}

Nearly $20 \%$ of the subjects took only one meal per day, $14 \%$ of the subjects took two meals per day, $66 \%$ of the subjects had four meals per day and none of the selected subjects took four or more than four meal per day.

3) Skipping Meals and Frequency of Skipping Meals: 


\section{International Advanced Research Journal in Science, Engineering and Technology}

Vol. 8, Issue 6, June 2021

\section{DOI: $10.17148 /$ IARJSET.2021.8604}

Around $48 \%$ of the subjects skipped meals and $52 \%$ of the subjects were stick on their regular meals. Nearly 10 subjects skipped breakfast daily, 17 subjects weekly once, seven subjects were skipped weekly twice and six subjects skip breakfast rarely. Eight subjects skipped lunch daily, 15 subjects skipped lunch once in a week, two subjects weekly twice and nine subjects rarely skipped their lunch. Five subjects skipped dinner daily, 10 subjects once in a week, four subjects weekly twice and five subjects rarely skipped their dinner.

\section{4) Reason for Skipping of Meal Among the Selected Subjects:}

It was found that 48 subjects skipped meals, in that nearly 26 subjects(54.1\%) skipped meals due to lack of time, 3 subjects $(6.3 \%)$ skipped meals because of stress, 7 subjects (14.6\%) because of lack of appetite, and 12 subjects (25\%) because work schedule.

\section{5) Food Allergy Among the Selected Subjects:}

It was reported that among the selected 100 subjects 8 subjects have food allergy and 92 subjects not have any allergic reactions towards food.

\section{Nutrient Intake of all the Selected Subjects -24 Hour Diet Recall}

The below table-2 depicts the nutrient intake of energy, fat, protein, fibre iron and calcium for all the selected subjects by 24 hour diet recall.

\section{1) Energy Intake:}

It was found that the average energy intake of the selected sedentary working subjects was 1712.8 kcal where their RDA is $1900 \mathrm{kcal}$. The deficit energy was $187.2 \mathrm{kcal}$. The average energy intake of the moderately working subjects was $1822.8 \mathrm{kcal}$ where their RDA is $2230 \mathrm{kcal}$. The deficit energy was $407.2 \mathrm{kcal}$. The average energy intake of the heavy working subjects was $1848.66 \mathrm{kcal}$ where their RDA is $2850 \mathrm{kcal}$. The deficit energy was $1001.34 \mathrm{kcal}$.

Table II NuTRIENT INTAKE OF ALL THE SELECTED SUBJECTS -24 HOUR DIET RECALL (N=100)

\begin{tabular}{|c|c|c|c|c|c|}
\hline \multicolumn{2}{|c|}{ Nutrients } & \multirow{2}{*}{$\begin{array}{l}\text { RDA* } \\
1900 \\
\end{array}$} & \multirow{2}{*}{$\begin{array}{c}\begin{array}{c}\text { Average } \\
\text { Intake }(\text { mean } \pm \text { SD) }\end{array} \\
1712.8 \pm 218.6 \\
\end{array}$} & \multirow{2}{*}{$\begin{array}{c}\text { Deficit } \\
187.2 \\
\end{array}$} & \multirow{2}{*}{$\begin{array}{c}\text { Excess } \\
- \\
\end{array}$} \\
\hline Energy & Sedentary & & & & \\
\hline (Kcals) & Moderate & 2230 & $1822.8 \pm 198.2$ & 407.2 & - \\
\hline & Heavy & 2850 & $1848.66 \pm 286.5$ & 1001.34 & - \\
\hline \multirow[t]{3}{*}{ Fat $(\mathrm{g})$} & Sedentary & 20 & $56.84 \pm 4.2$ & - & 36.84 \\
\hline & Moderate & 25 & $60.4 \pm 3.4$ & - & 35.4 \\
\hline & Heavy & 30 & $46 \pm 2.4$ & - & 16 \\
\hline \multicolumn{2}{|c|}{ Protein $(\mathrm{g})$} & 55 & $47.39 \pm 5.6$ & 7.61 & - \\
\hline \multicolumn{2}{|c|}{ Fibre (g) } & 25 & $16.32 \pm 2.4$ & 8.68 & - \\
\hline \multicolumn{2}{|c|}{ Iron $(\mathrm{mg})$} & 21 & $5.72 \pm 1.8$ & 15.28 & - \\
\hline \multicolumn{2}{|c|}{ Calcium (mg) } & 600 & $419.11 \pm 62.7$ & 180.89 & - \\
\hline
\end{tabular}

*Recommended Dietary Allowance (2010)

2) Fat Intake:

The average fat intake of the sedentary working subjects was $56.84 \mathrm{~g}$ where their RDA is only $20 \mathrm{~g}$. The excess fat intake was calculated as $36.84 \mathrm{~g}$. The average fat intake of the moderate working subjects was $60.4 \mathrm{~g}$ where their RDA is only $25 \mathrm{~g}$. The excess fat intake was calculated as $35.4 \mathrm{~g}$. The average fat intake of the heavy working subjects was 46 where their RDA is $30 \mathrm{~g}$. The excess fat intake was calculated as $16 \mathrm{~g}$.

3) Protein, Fibre, Iron and Calcium Intake:

The average protein intake per day of the subjects was $47.39 \mathrm{~g}$ and the RDA is $55 \mathrm{~g}$. The deficit protein intake was $7.61 \mathrm{~g}$. The average fibre intake per day of the subjects was $16.32 \mathrm{~g}$ and the RDA is $25 \mathrm{~g}$. The deficit fibre intake was $8.68 \mathrm{~g}$. The average iron intake per day of the subjects was $5.72 \mathrm{mg}$ and the RDA is $21 \mathrm{mg}$. The deficit iron intake was $15.28 \mathrm{mg}$. The average calcium intake per day of the subjects was $419.11 \mathrm{mg}$ and the RDA is $600 \mathrm{mg}$. The deficit calcium intake was $180.89 \mathrm{mg}$.

\section{E. Stress Level of the Selected Subjects}

1) Perceived Stress Scale of all the Selected Subjects:

It was observed that for the question how often have you been upset because of something that happened unexpectedly, nearly 54 selected subjects answered sometimes and nine subjects reported fairly. For the question how often have you felt that you were unable to control the important things in your life, around 43 reported as sometimes and 15 said very often. For the question in the last month, how often have you felt nervous and stressed, nearly 45 told sometimes and 13 reported very often. It was answered sometimes by 51 subjects and never by 16 subjects for the question how often have you been angered because of things that happened that were outside of your control. Nearly 35 answered sometimes and 13 reported as very often for the question, in the last month, how often have you felt difficulties were piling up so high that you could not overcome them. 
Vol. 8, Issue 6, June 2021

DOI: $10.17148 /$ IARJSET.2021.8604

2) Stress Score of the Selected Subjects:

About $72 \%$ of the subjects were under moderate stress, $28 \%$ of the subjects were under high stress and none of the subjects have very low stress.

\section{F. Relationship Between Stress Level and Nutrient Intake Among the Selected Subjects}

SPSS version 19 statistical tool was used to analyze the data. It was observed that the $\mathrm{p}$-values are greater than the level of significance $(\mathrm{P}>0.05)$. It shows that there is no relationship between nutrient intake and stress level. So it is assumed that the stress may be due to the work tension or any other physiological conditions.

\section{G. Provision of Nutrition Education to all the Selected Subjects}

Nutrition education was provided to all the selected working women. Pamphlet was prepared by the investigators on importance of breakfast, healthy food choices and physical activity. Individual counseling was provided to all the selected subjects regarding their nutrient intake. The selected 100 subjects were divided in to four groups and each group was assigned to one investigator for individual counseling. The counseling session to selected subjects was about to maintain anthropometric status, initiate physical activity, to regularize the meal pattern, nutrient intake and healthy food choices. The session lasted for about 30 minutes.

\section{CONCLUSION}

Technological development although have changes the lifestyle and elevated the social status of women. Most of the time the women who take care of the health and nutrition of the family ignores own health. The present study shows that the nutritional status of the working women is low which may be due to skipping of meals and inadequate nutrient intake. The stress among working women was moderate to high which may be caused by increased work responsibilities. The study also indicates that there is no relationship between nutrient intake and stress level. The task of juggling home and job responsibilities is not always stressful; many women appear to be very resourceful in coping with potentially conflicting demands. Sound knowledge about good nutrition and balanced diet will help to promote healthy food habits among working women and also stress can be regulated by physical activities like exercises, yoga and meditation.

\section{REFERENCES}

[1] Meenakshi Mathur, Monika Harsh, and .umita Mathur. Dept. of Home Science, JNV University, Jodhpur, India. Diet Pattern and Nutritional Status of Women Working in Call Centers of India. International Journal of Food Engineering Vol. 1, No. 2, December (2015). doi: 10.18178/ijfe.1.2.127-133

[2] Jyothi Lakshmi A. and Jamuna Prakash. Maternal characteristics and nutritional health status of rural children: An overview. The Indian journal of Nutrition and Dietetics. (2004). Volume 41, Issue 1,P:12

[3] Rachappa Pallavi, Ranganath Deepa, Chandra shekar Sudharma Devaki. A Study on Assessment of Nutritional Status and Nutritional Knowledge of Working Women at Mysuru City. Journal of food processing and technology (2020) Vol.11 Iss.8 No:841 Website references

[4] https://www.cleverism.com/interview-schedule-definition-types-templates-tips/

[5] https://www.dshs.wa.gov/altsa/program-services/nutrition-education 